\title{
Altered Erythrocyte C3b Receptor Expression, Immune Complexes, and Complement Activation in Homosexual Men in Varying Risk Groups for Acquired Immune Deficiency Syndrome
}

\author{
Francisco A. Tausk, J. Allen McCutchan, Phyllis Spechko, Robert D. Schreiber, and Irma Gigli \\ Division of Dermatology and Division of Infectious Diseases, University of California at San Diego School of Medicine, San Diego, \\ California 92103; and Department of Pathology, Washington University School of Medicine, St. Louis, Missouri 63130
}

\begin{abstract}
We studied levels of erythrocyte C3b receptors (E-CR1) and correlated them to the level of circulating immune complexes (CIC) and complement activation in patients with or at risk for acquired immunodeficiency syndrome (AIDS). A significant reduction was found in patients with AIDS (185 \pm 93 CR1/cell), AIDS-related complex, and generalized lymphadenopathy, whereas healthy male homosexuals or normal controls had $434 \pm 193$ and $509 \pm 140 \mathrm{CR1} /$ cell, respectively $(P<0.001)$. Family studies indicate that this defect is acquired. Reduction in E-CR1 was associated with increased levels of CIC when assayed by binding to Raji cells, but not when tested by C1q binding. Complement activation was assessed by levels of C3bi/ C3d-g in plasma, measured with a monoclonal antibody specific for a neoantigen in C3d. AIDS patients had increased C3 activation $(2.68 \pm 1.67 \%)$ when compared with normal controls $(0.9 \pm 0.22 \%)(P<0.01)$. The decreased E-CR1, the presence of $\mathrm{CIC}$, and $\mathrm{C} 3$ activation suggest that complement activation by immune complexes may play a role in the clinical expression of the disease.
\end{abstract}

\section{Introduction}

The CR1 receptor, a glycoprotein that binds to the $\mathrm{C} 3 \mathrm{~b}$ and $\mathrm{C} 4 \mathrm{~b}$ fragments of the complement system, is expressed in a variety of blood and tissue cells (1-6). Erythrocytes, because they are so large in number compared with other circulating blood cells, carry on their surface the majority of the circulating pool of this receptor (7). CR1 appears to endow these cells with the capacity to clear circulating immune complexes $(\mathrm{CIC})^{1}$ by transporting them to the liver where they are removed by local macrophages $(8,9)$. In addition, $C R 1$ acts as cofactor of factor $I$ in the inactivation of $\mathrm{C} 3 \mathrm{~b}$ and $\mathrm{C} 4 \mathrm{~b}(2,10-12)$.

Diseases involving autoantibodies and CIC, such as systemic lupus erythematosus (SLE), rheumatoid arthritis, cold agglutinin disease, hemolytic anemias, and lepromatous leprosy, are as-

Received for publication 2 April 1986.

1. Abbreviations used in this paper: AIDS, acquired immune deficiency syndrome; ARC, AIDS-related complex; ATBS, 2,2-azino-di[3 ethylbenzthiazoline]; BBS, borate-buffered saline; CIC, circulating immune complexes; CVF, cobra venom factor; E-CR1, erythrocyte-C3b receptor; ELISA, enzyme-linked immunoabsorbent assay; HTLV-III, human T cell leukemia/lymphotropic virus III; SLE, systemic lupus erythematosus.

J. Clin. Invest.

(c) The American Society for Clinical Investigation, Inc.

0021-9738/86/10/0977/06 \$1.00

Volume 78, October 1986, 977-982 sociated with low levels of erythrocyte CR1 (E-CR1) (13-17). This defect may play a role in the pathogenesis of some of their clinical and immune abnormalities. Low E-CR 1 in SLE patients appears to be inherited (15-18), but recent studies suggest that acquired factors, such as disease activity (14), autoantibodies against the receptor (19), and immune complexes bearing fragments of C3, are involved (16).

Although a retrovirus has been identified as the probable cause of acquired immune deficiency syndrome (AIDS) (2021 ), the pathogenesis of many of its clinical manifestations is not understood. In spite of the fact that immune complexes are apparently involved in AIDS-related thrombocytopenia (22) and glomerulitis (23), previous studies of CIC are controversial (2429 ), and lack of complement activation has been reported (3032). Complement activation, immune complexes, and their clearance by E-CR 1 could influence some of the clinical manifestations of AIDS, therefore we studied these variables in homosexual subjects at varying risk of developing AIDS.

\section{Methods}

Study population. Subjects seen at the Medical Center of the University of California at San Diego in a longitudinal study of homosexual male volunteers were classified in the following groups: (A) patients who fulfilled the criteria for AIDS, (B) patients who fulfilled the Center for Disease Control/National Institutes of Health criteria for AIDS-related complex (ARC), (C) homosexual men with generalized lymphadenopathy, (D) asymptomatic homosexual men who presented with at least one laboratory abnormality suggesting immune deficiency, such as leukopenia, anemia, depressed helper/suppressor $\mathrm{T}$ lymphocyte ratios $(<1.0)$, or skin anergy, $(E)$ healthy homosexual men, and $(F)$ relatives of patients with AIDS. The control population (G) consisted of 55 healthy heterosexual Caucasian males ranging in age from 19 to $56 \mathrm{yr}$.

Purification of CRI and production of anti-CRI monoclonal antibodies. CR1 was purified to homogeneity from human erythrocytes as previously described (17). Mice were immunized by two intraperitoneal injections with $10 \mu \mathrm{g}$ of purified CR1. Spleen cells were fused with the murine myeloma line $P 3 \times 63$.AG8.653 at a ratio of 6:1. The antibodies produced by clone 543 were tested using purified CR1 in an enzymelinked immunoabsorbent assay (ELISA). The ascites fluid was passed through a protein A-agarose column (E-Y Laboratories, San Mateo, CA)

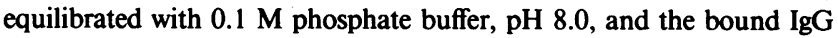
was eluted with $0.1 \mathrm{M}$ acetic acid. Fab' fragments were obtained by digesting the IgG with $2 \%$ wt/wt pepsin (Sigma Chemical Co., St. Louis, $\mathrm{MO}$ ) for $18 \mathrm{~h}$ at $37^{\circ} \mathrm{C}, \mathrm{pH} 4$, in the presence of $0.02 \mathrm{M} \mathrm{Cys-HCl}$ (Sigma Chemical Co.); $0.025 \mathrm{M}$ iodoacetamide was then added and the fragments were purified by high performance liquid chromatography (Waters Associates, Millipore Corp., Milford, MA) gel filtration on a $7.5 \times 600$ mm TSK-250 column (Bio-Rad Laboratories, Richmond, CA).

Quantitation of E-CRI. A radiobinding assay was utilized to measure the number of CR 1 molecules on the erythrocyte surface, using ${ }^{125}$ I Fab' $^{\prime}$ fragments of a monoclonal antibody directed against the receptor. 10 $\mathrm{ml}$ of venous blood were drawn in 0.02 M EDTA (Fisher Scientific Co., Fairlawn, NJ). The cells were washed in veronal-buffered saline, and the 
buffy coat removed after each wash. The erythrocytes were then resuspended at a concentration of $2.5 \times 10^{9} / \mathrm{ml}$ in veronal-buffered saline $(0.075 \mathrm{M} \mathrm{NaCl})$ containing $2.5 \%$ dextrose (Mallinkrodt, Inc., St. Louis, MO), and $0.5 \%$ gelatin (J. T. Baker Chemical Co., Phillipsburg, NJ). 50 $\mu$ lof erythrocytes were incubated on ice with $50 \mu$ l of increasing dilutions of ${ }^{125} \mathrm{I} \mathrm{Fab}$ anti-CR 1 in dextrose/gelatin/veronal buffer ranging from 6.5 to $0.4 \mu \mathrm{g} / \mathrm{ml}$. After $60 \mathrm{~min}$, the mixtures were layered on $200 \mu \mathrm{l}$ of dibutylphthalate (Eastman Kodak Co., Rochester, NY), and after centrifugation for $1 \mathrm{~min}$ in a microfuge (Beckman Instruments Inc., Palo Alto, CA), the pellets and supernatants were measured for bound and free ${ }^{125} \mathrm{I}-\mathrm{Fab}^{\prime}$. Nonspecific binding was determined by incubating the samples for $60 \mathrm{~min}$ with 200 -fold excess of unlabeled anti-CR 1 IgG before adding the ${ }^{125} \mathrm{I}-\mathrm{Fab}^{\prime}$. The number of $\mathrm{CR} 1$ per cell was calculated by binding isotherms and Scatchard analysis of the binding data (33).

Evaluation of circulating anti-CRI autoantibodies. Venous blood was allowed to clot at room temperature and the serum stored at $-70^{\circ} \mathrm{C}$. Duplicate wells of flat bottomed Immulon I microtiter plates (Dynatech Laboraties, Inc., Alexandria, VA) were coated overnight at $4^{\circ} \mathrm{C}$ with 50 $\mu \mathrm{l}$ of carbonate-bicarbonate buffer, $\mathrm{pH} 9.6$, containing either $10 \mathrm{ng}$ of purified CR1 or $1 \%$ human serum albumin (Sigma Chemical Co.). After removing the supernatants, the wells were washed with borate buffered saline (BBS) at $\mathrm{pH} 7.5$, and incubated for $2 \mathrm{~h}$ at $22^{\circ} \mathrm{C}$ with BBS/ $1 \% \mathrm{HSA}$ to block nonspecific binding sites. Undiluted human serum or rabbit anti-CR $1(6 \mu \mathrm{g} / \mathrm{ml})$ were added to the wells and incubated for $1 \mathrm{~h}$ at $22^{\circ} \mathrm{C}$, after which they were washed with $\mathrm{BBS} / 1 \%$ human serum albumin containing $0.05 \%$ Tween 20 (Bio-Rad Laboratories). The wells containing human serum were incubated for $1 \mathrm{~h}$ at $22^{\circ} \mathrm{C}$ with $100 \mathrm{ng}$ of peroxidaseconjugated goat anti-human IgG or IgM (Atlantic Antibodies, Scarborough, ME). Those wells containing rabbit anti-CR1 received $100 \mathrm{ng}$ of peroxidase-conjugated goat anti-rabbit IgG (Atlantic Antibodies) in $\mathbf{5 0}$ $\mu$ l of TBBS-HSA. The reactions were developed with 2,2-azino-di[3 ethylbenzthiazoline] (ATBS) (Zymed, San Francisco, CA) for $30 \mathrm{~min}$ and the optical density measured at $410 \mathrm{~nm}$ in a Minireader II (Dynatech Laboratories, Inc.). A standard curve was constructed by incubating serial dilutions of peroxidase anti-IgG or -IgM with ATBS for $30 \mathrm{~min}$. This curve was compared with the results obtained from the test serum samples and expressed as nanograms of conjugated antibody bound.

Quantitation of $\mathrm{C} 3 \mathrm{bi} / \mathrm{C} 3 \mathrm{~d}-\mathrm{g}$ in plasma. Venous blood was drawn in vacutainers containing EDTA, chilled on ice for $1 \mathrm{~h}$, centrifuged for 30 min at $30,000 \mathrm{~g}$ and the plasma was stored at $-70^{\circ} \mathrm{C}$. The samples were tested within $15 \mathrm{~d}$ as follows. Duplicate Immulon I microtiter wells were coated overnight at $4^{\circ} \mathrm{C}$ with $50 \mu \mathrm{l}$ of BBS, pH 7.5, containing $300 \mathrm{ng}$ of anti-C3bi/C3d-g monoclonal IgG (kindly supplied by Dr. H. MüllerEberhard, Scripps Clinic and Research Foundation, La Jolla, CA) or with $1 \%$ bovine serum albumin (BSA) (Sigma Chemical Co.) in BBS (BBS-BSA), pH 7.5. The plates were washed and incubated for $2 \mathrm{~h}$ with $250 \mu$ l of $1 \%$ BSA to cover unreacted sites, followed by washing with BBS-BSA. $50 \mu \mathrm{l}$ of serial dilutions of test plasma in BBS-BSA containing $0.05 \%$ Tween 20 were added and incubated for $1 \mathrm{~h}$. Additional wells were reacted with serum in which the complement system was activated by incubation with cobra venom factor (CVF) (Cordis Laboratories, Inc., Miami, FL) $(34,35)$. The wells were then washed and reacted for 60 min with $500 \mathrm{ng}$ of rabbit anti-C3d (Accurate Chemical \& Scientific Corp., Westbury, NY) that was previously absorbed with mouse serum coupled to sepharose beads. After washing, $12.5 \mathrm{ng}$ of peroxidase-conjugated goat anti-rabbit IgG antibodies (Atlantic Antibodies) were added, and the reactions were developed with ATBS for $30 \mathrm{~min}$. The optical density in each sample was measured at $410 \mathrm{~nm}$ in a Minireader II. Linear regression analysis of the different dilutions of the tested plasma were compared with those obtained from the CVF-activated serum and expressed as percentages of total complement activation.

Measurement of CIC. The presence of CIC was assessed in serum by Clq binding (36) and Raji cell assays (37).

Anti-human $T$ cell leukemia/lymphotrophic virus (HTLV-III) serology. Antibodies to the AIDS retrovirus (HTLV-III) were determined by ELISA, using microtiter plates (Electro-Nucleonics, Inc., Fairfield, $\mathrm{NJ})$.

\section{Results}

Quantitation of CRI on erythrocytes. The mean number of CR 1 per erythrocyte $( \pm S D)$ for each group of subjects is shown in Fig. 1. 29 patients with AIDS (A) had 185 \pm 93 E-CR1 and 4 with ARC (B) had $273 \pm 94$; 49 patients with generalized lymphadenopathy (C) had $372 \pm 143$, and 17 asymptomatic patients with mild immune abnormalities (D) had $429 \pm 161$. The number of E-CR1 in 17 healthy homosexual men and 55 heterosexual controls were $434 \pm 193$ and $509 \pm 140$, respectively. Analysis by Duncan's multiple range test showed a significant difference between the normal controls and groups A, B, and C, but not with groups $\mathrm{D}$ and $\mathrm{E}$. There was no significant difference between patients with AIDS who had Kaposi's sarcoma and those with opportunistic infection $(P=0.44)$. Histograms and the Anderson-Darling test obtained from the data points of the healthy population and patients revealed a normal distribution.

To establish whether the impaired expression of CR 1 in AIDS patients is inherited or acquired, we studied 15 of their relatives. Their mean number of CR 1 per cell $(505 \pm 210)$ does not differ from the normal population. Furthermore, in one family, the patient had $<200 \mathrm{E}-\mathrm{CR} 1$, whereas his parents and sibling had between 600 and $786 \mathrm{E}-\mathrm{CR} 1$. Although the propositus in another family had 195 E-CR1, his parents had 850 and 425 E-CR1. These family studies suggest that the defect of E-CR 1 in patients with AIDS is acquired.

Anti-CRI autoantibodies in plasma. Because the presence of anti-CR1 autoantibodies could account for the decrease in the number of receptors as recently reported in one patient with SLE (19), we measured these antibodies by ELISA in the plasma of 9 normal subjects and 13 patients with AIDS. With purified CR1 as antigen to coat wells, normal human sera bound a mean of $0.16 \pm 0.09 \mathrm{ng}$ of peroxidase goat anti-human $\mathrm{IgG}$ and $0.38 \pm 0.33 \mathrm{ng}$ of anti-human IgM, while patients with AIDS bound only $0.07 \pm 0.05 \mathrm{ng}$ and $0.13 \pm 0.12 \mathrm{ng}$, respectively. In agreement with Wilson et al. (19), we found that normal sera may contain small amounts of what appear to be circulating anti-CR1 antibodies, but this amount is not increased in patients with AIDS. These results indicate that anti-CR1 autoantibodies are not involved in the reduction of E-CR 1 in AIDS.

CIC. Raji cell assay showed CIC in 13 out of 20 patients in group A, 12 out of 12 in group C, 4 out of 6 in group D, and 3 out of 6 in group E (Fig. 2). The highest levels of CIC were found in group C. Linear regression analysis showed a significant correlation between the levels of CIC and the titer of anti-HTLVIII antibodies $(r=0.58, P<0.001)$ (Fig. 3). When immune complexes were measured using the ${ }^{125} \mathrm{I}-\mathrm{Clq}$ binding assay, all the sera tested were negative.

Complement activation in plasma. Previous studies have reported normal values of total complement activity (CH50) as well as of $\mathrm{C} 3$ and $\mathrm{C} 4$ in patients with AIDS. Because reactive production may normalize circulating levels of complement proteins in the presence of complement activation, we examined the plasma levels of $\mathrm{C} 3 \mathrm{bi} / \mathrm{C} 3 \mathrm{~d}-\mathrm{g}$ as an indicator of complement consumption. We measured this product with an ELISA, using a monoclonal antibody directed to an epitope present in $\mathrm{C} 3 \mathrm{bi}$, $\mathrm{C} 3 \mathrm{~d}-\mathrm{g}$, and $\mathrm{C} 3 \mathrm{~d}$ and absent in native $\mathrm{C} 3$ or $\mathrm{C} 3 \mathrm{~b}$ (38). Each plasma sample tested was compared with a standard normal human serum control that was activated with CVF and assumed to represent $100 \%$ of activation of C3. Results, expressed as a percentage of $\mathrm{C} 3$ activation, show that there is a statistically sig- 


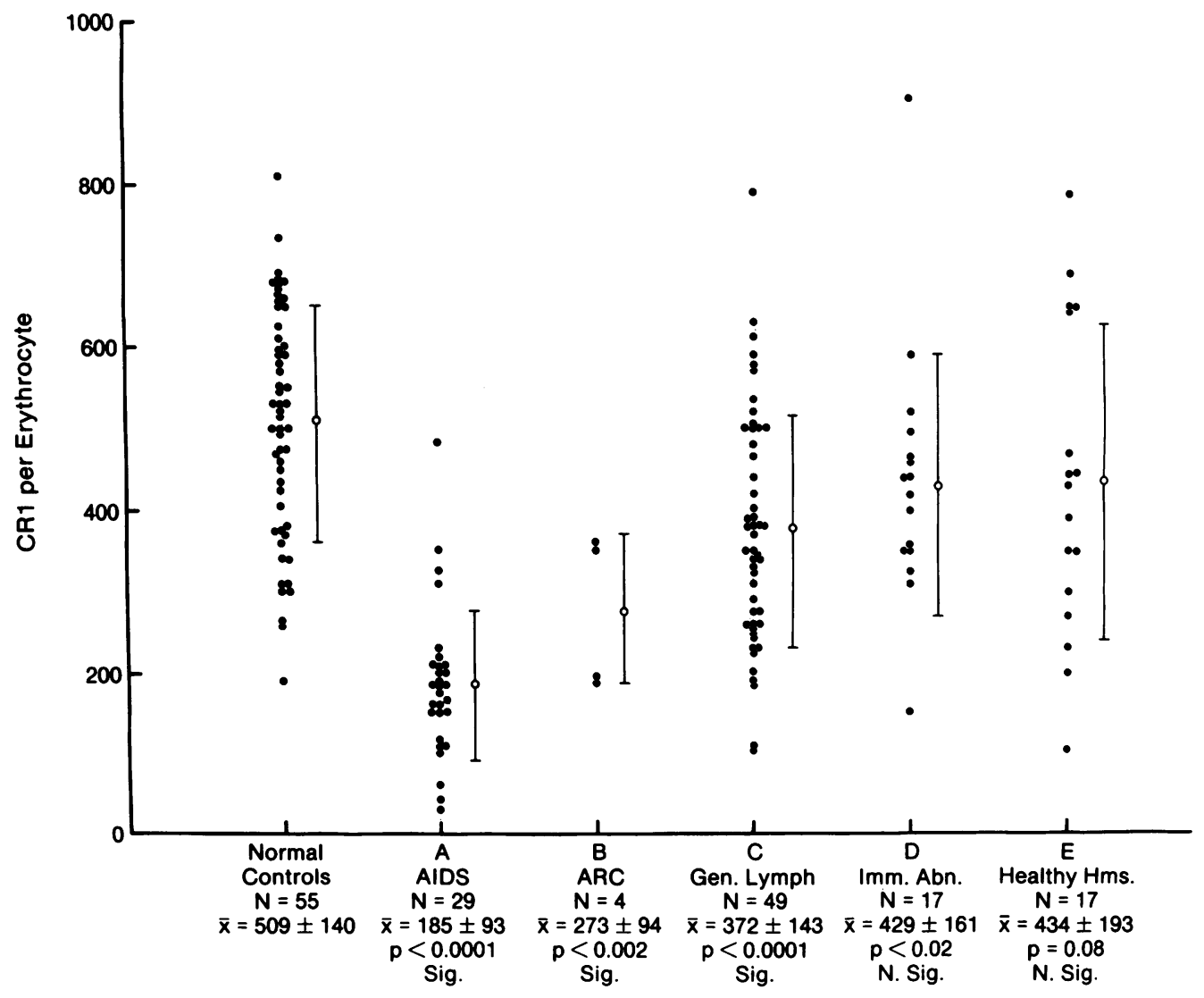

Figure 1. Quantitation of E-CR 1 with ${ }^{125}$ I-Fab' fragments of monoclonal anti-CR1 antibody. Means \pm SD for each group studied are shown; $P$ values are the result of individual $t$ tests between each group and the normal population. The result of Duncan's multiple range test for the comparison of the means of studied groups and normals is expressed as significant (Sig.) or nonsignificant (N. Sig.). Gen. Lymph, patients with generalized lymphadenopathy; Imm. Abn., homosexual men with immune abnormalities; Healthy Hms., healthy homosexual males.

nificant difference between patients with AIDS and all other groups by Duncan's multiple range test. No difference was observed between patients who had Kaposi's sarcoma and those with opportunistic infection $(P=0.69)$. No significant difference was found between patients of groups $C, D$, and $E$ and the normal population (Fig. 4). There was a negative correlation between $\mathrm{C} 3$ activation and E-CR $1(r=-0.439 ; P=0.002)$. No correlation was found between CIC measured by Raji cell assay and C3 activation $(r=0.120)$.

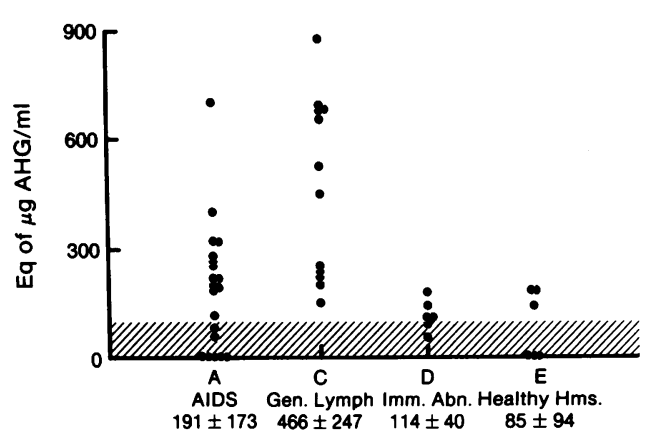

Figure 2. Measurement of CIC by the Raji cell assay. Results are expressed as equivalents of micrograms of aggregated gamma globulin per milliliter of serum (eq of $\mu \mathrm{g} \mathrm{AHG/ml).} \mathrm{The} \mathrm{normal} \mathrm{population} \mathrm{has}$ $<100$ (shaded area). No significant difference was observed between AIDS patients (group A) with Kaposi's sarcoma and those with opportunistic infection $(P=0.44)$. Gen. Lymph, generalized lymphadenopathy; Imm. Abn., patients with immune abnormalities; Healthy Hms., healthy homosexual males.

\section{Discussion}

The $\mathrm{C} 3 \mathrm{~b} / \mathrm{C} 4 \mathrm{~b}$ receptor was described more than $30 \mathrm{yr}$ ago as the immune adherence receptor (39). It has been characterized as a polymorphic glycoprotein (40) that regulates complement activation at the host cell surface, functions in the processing of immune complexes, and participates in a variety of host-cell-

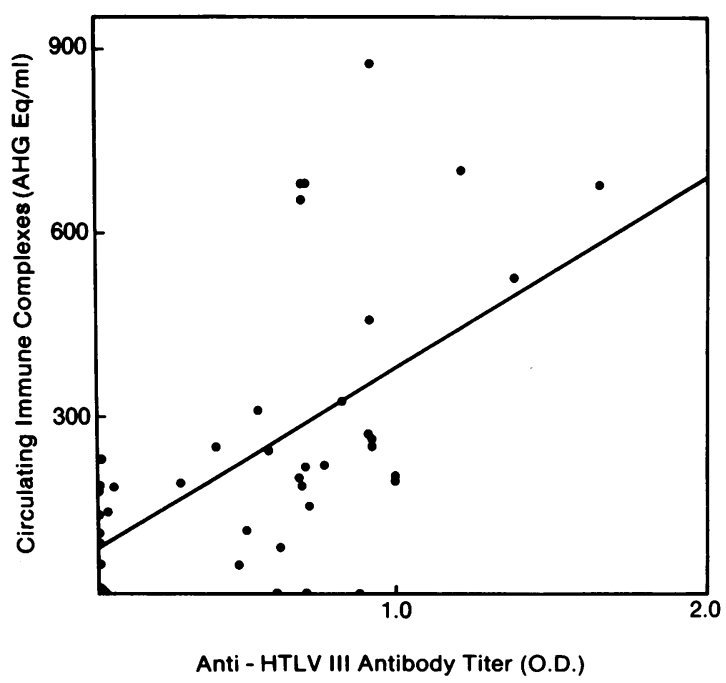

Figure 3. Relationship between titers of anti-HTLV III antibodies and circulating immune complexes in 20 patients with AIDS, 2 with ARC, 12 with generalized lymphadenopathy, 6 homosexual males with immune abnormalities, and 6 healthy homosexual men. 


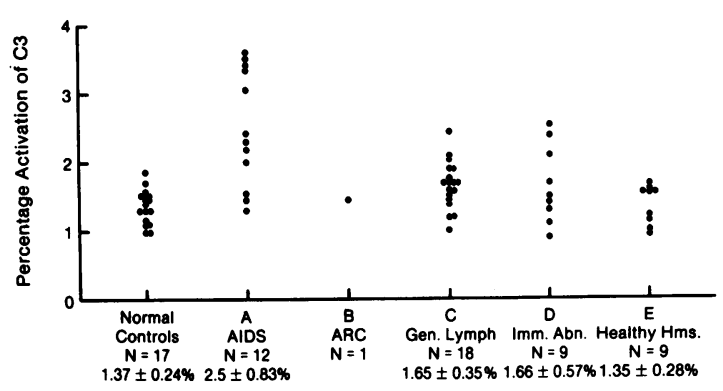

Figure 4. Complement activation in plasma measured by the quantitation of circulating $\mathrm{C} 3 \mathrm{bi} / \mathrm{C} 3 \mathrm{~d}-\mathrm{g}$ fragment. Results are expressed as percentage of total C3 activation produced by CVF. Gen. Lymph, generalized lymphadenopathy; Imm. Abn., immune abnormalities; Healthy Hms., healthy homosexual males.

mediated defense reactions (41). The observation that patients with autoimmune diseases such as SLE have a significant decrease in the number of CR1 molecules on the surface of their erythrocytes suggests that this receptor may be of significance in the expression of some clinical manifestations.

Using a monoclonal antibody to quantitate the expression of $\mathrm{C} 3 \mathrm{~b}$ receptors (CR 1 ) on the surface of erythrocytes, we found decreased levels in patients with AIDS, ARC, and generalized lymphadenopathy compared with levels in asymptomatic homosexual and heterosexual men. Most patients with AIDS and ARC have a severe reduction in the expression of E-CR 1 when compared with healthy heterosexuals. The only patient with AIDS who had normal levels of E-CR1 (479) presented with a solitary lesion of Kaposi's sarcoma in the parotid gland, which was removed and has not recurred in $12 \mathrm{mo}$. Many AIDS patients with Kaposi's sarcoma are less severely compromised immunologically than those with opportunistic infections. This patient had decreased helper $T$ cells and anergy to skin tests, but no other evidence of severe immune suppression.

Two patients who originally had only lymphadenopathy and low CR1 subsequently developed AIDS. One of them had 170 E-CR1 when first tested, and 116 when diagnosed as having AIDS 9 mo later; the other patient had 330 when first seen, and 200 E-CR 1 after developing opportunistic infections. Long-term follow-up of other subjects in groups $C, D$, and $E$ will determine whether E-CR1 reliably predicts which infected individuals eventually develop AIDS.

A number of studies have examined the mechanism of the reduction of E-CR 1 in autoimmune diseases such as SLE. Wilson et al. (15) proposed the concept of an inherited defect based on the observation that relatives of SLE patients presented the same alteration. They concluded that two codominant alleles determined the low levels in SLE patients as well as in their relatives, and proposed that individual expression of CR1 falls into three genetically determined groups: high, intermediate, and low. This notion is also supported by reports from Minota et al. (18). In contrast, lida et al. (14), Ross et al. (16), and Walport et al. (42) have shown that low CR1 in patients with SLE was influenced by factors related to the disease activity. Although evidence exists to support the inherited determination of E-CR1 levels in the normal population $(15,42)$, the nature of the reduction observed in SLE patients remains unclear. In order to address this question in AIDS, we examined E-CR 1 in relatives of patients with AIDS and observed that the mean number did not differ from the normal population. In two families, the altered expression of E-CR1 in the patients could not be attributed to codominant inheritance, indicating that it is acquired. Histograms of E-CR1 of healthy controls and patients showed a normal distribution, in agreement with the findings of Ross et al. (16).

Previous reports of immune complexes in patients with AIDS present contradictory results (24-29). This controversy could stem from the use of different assays to measure CIC. This question encouraged us to compare two different methods in the evaluation of our subjects. We found that $65 \%$ of patients in group A, $100 \%$ of those in group C, $66 \%$ in group D, and $50 \%$ in group E had elevated levels of CIC by the Raji cell assay. In contrast, none had CIC detectable in their plasma by the Clq binding assay. Therefore, it appears that the CIC in patients with AIDS bear $\mathrm{C} 3 \mathrm{bi}$ fragments and not $\mathrm{Clq}$, activating the alternative but not the classical pathway. Similar results were obtained by Gupta and Licorish (43) in a limited study of patients with AIDS and ARC. The decreased levels of CIC, as well as anti-HTLVIII antibody titers in patients with AIDS, when compared to subjects with lymphadenopathy, could reflect the impaired humoral immune response to specific antigens in $\operatorname{AIDS}(44,45)$.

Our finding that $\mathrm{C} 3$ cleavage products $(\mathrm{C} 3 \mathrm{bi} / \mathrm{C} 3 \mathrm{~d}-\mathrm{g})$ are elevated in the plasma of AIDS patients suggests that there is activation of the complement system. Reactive production of complement proteins may account for the normal $\mathrm{CH} 50$ values, as well as the normal levels of $\mathrm{C} 3$ and $\mathrm{C} 4$ previously reported. Because C3d has recently been shown to be a potent stimulator of activated B cells (46), the increased C3d-g in the circulation of patients with AIDS could serve as positive feedback in the production of CIC.

The exact mechanism of reduced expression of E-CR1 in AIDS is unknown. We have shown that patients with AIDS do not have circulating anti-CR1 autoantibodies and that the monoclonal anti-CR1 antibody that we used recognizes the receptor independently of receptor occupancy (17). Thus, the immune complexes observed do not interfere with the measurement of the receptor. Ross et al. (16) proposed that in SLE patients, CR1 may be lost during the interaction of complement-bearing erythrocytes with liver or spleen macrophages. Our findings of increased CIC and complement activation in AIDS patients could support a similar mechanism in AIDS. Another possibility is that an E-CR1 synthetic defect arises in the bone marrow. A biochemical abnormality of erythrocytes in AIDS (increased adenosine deaminase activity), which could result from a direct effect of the AIDS retrovirus on erythroid precursors (47), has recently been reported. Alternatively, the receptor could be lost during the maturation of erythroid cells in a manner similar to the decreased expression of the decay accelerating factor in patients with paroxysmal nocturnal hemoglobinuria (48).

Regardless of the mechanism of E-CR 1 reduction, the presence of CIC, decreased E-CR1, and complement activation could influence the pathogenesis, clinical expression, and prognosis of AIDS.

\section{Acknowledgments}

The authors wish to express their appreciation to Mr. Michael Hagan for excellent technical assistance and Ms. Susan Krayzel for invaluable help in the preparation of this manuscript.

This work was supported by National Institutes of Health grant AI20476 and by a grant from the University of California, Universitywide Task Force on AIDS. Dr. Tausk is the recipient of the Society of Inves- 
tigative Dermatology Research Fellowship awarded by the Dermatology Foundation. Statistical analysis was performed in a VAX 11/750, General Clinical Research Center, University of California at San Diego, San Diego, CA (National Institutes of Health grant RR-00827).

\section{References}

1. Fearon, D. T. 1979. Regulation of the amplification C3 convertase of human complement by an inhibitory protein isolated from human erythrocyte membrane. Proc. Natl. Acac. Sci. USA. 76:5867-5871.

2. Medof, E., and V. Nussenzweig. 1984. Control of the function of substrate-bound $\mathrm{C} 4 \mathrm{~b}-\mathrm{C} 3 \mathrm{~b}$ by the complement receptor CR1. J. Exp. Med. 159:1669-1685.

3. Fearon, D. T. 1980. Identification of the membrane glycoprotein that is the $\mathrm{C} 3 \mathrm{~b}$ receptor of the human erythrocyte, polymorphonuclear leukocyte, B lymphocyte, and monocyte. J. Exp. Med. 152:20-30.

4. Wilson, J. G., T. F. Tedder, and D. T. Fearon. 1984. Characterization of human $\mathrm{T}$ lymphocytes that express the $\mathrm{C} 3 \mathrm{~b}$ receptor. J. Immunol. 131:684-689.

5. Kazatchkine, M. D., D. T. Fearon, M. D. Appay, C. Mandet, and J. Bariety. 1982. Immunohistochemical study of the human glomerule $\mathrm{C} 3 \mathrm{~b}$ receptor in normal kidney and in seventy-five cases of renal diseases. J. Clin. Invest. 69:900-911.

6. Burke, K. E., and I. Gigli. 1980. Receptors for complement on Langerhans cells. J. Invest. Dermatol. 75:46-51.

7. Medof, M. E., and J. F. Oger. 1982. Competition for immune complexes by red cells in human blood. J. Clin. Lab. Immunol. 7:7-13.

8. Cornacoff, J. B., L. A. Herbert, W. L. Smead, M. E. Van Aman, D. J. Birmingham, and F. J. Waxman. 1983. Primate erythrocyte immune complex clearing mechanism. J. Clin. Invest. 71:236-247.

9. Waxman, F. J., L. A. Herbert, J. B. Cornacoff, M. E. Van Aman, W. L. Smead, E. H. Kraut, D. J. Birmingham, and J. M. Taguian. 1984. Complement depletion accelerates the clearance of immune complexes from the circulation of primates. J. Clin. Invest. 74:1329-1340.

10. Medof, M. E., K. Iida, C. Mold, and V. Nussenzweig. 1982. Unique role of the complement receptor CR1 in the degradation of $\mathrm{C} 3 \mathrm{~b}$ associated with immune complexes. J. Exp. Med. 156:1739-1754.

11. Ross, G. D., J. D. Lambris, J. A. Cain, and S. L. Newman. 1982. Generation of three different fragments of bound $\mathrm{C} 3$ with purified factor I or serum. I. Requirements for factor $\mathrm{H}$ vs. CRI cofactor activity. $J$. Immunol. 129:2051-2060.

12. Medicus, R. G., J. Melamed, and M. A. Arnaout. 1983. Role of human factor I and $\mathrm{C} 3 \mathrm{~b}$ receptor in the cleavage of surface-bound $\mathrm{C} 3 \mathrm{bi}$ molecules. Eur. J. Immunol. 13:465-470.

13. Miyakawa, Y., A. Yamada, K. Kosaka, F. Tsuda, E. Kosugi, and M. Mayumi. 1981. Defective immune-adherence (C3b) receptor on erythrocytes from patients with systemic lupus erythematosus. Lancet. ii:493-497.

14. Iida, K., R. Mornaghi, and V. Nussenzweig. 1982. Complement receptor CR1 deficiency in erythrocytes from patients with systemic lupus erythematosus. J. Exp. Med. 155:1427-1438.

15. Wilson, J. F., W. W. Wong, P. H. Schur, and D. T. Fearon. 1982. Mode of inheritance of decreased C3b receptors on erythrocytes of patients with systemic lupus erythematosus. N. Engl. J. Med. 307:981986.

16. Ross, G., W. J. Young, M. J. Walport, J. B. Winfield, C. J. Parker, C. R. Fuller, R. P. Taylor, B. L. Myones, and P. J. Lachmann. 1985. Disease-associated loss of erythrocyte complement receptors (CR1, C3b receptors) in patients with systemic lupus erythematosus and other diseases involving autoantibodies and/or complement activation. $J$. Immunol. 135:2005-2014.

17. Tausk, F., T. Hoffmann, R. Schreiber, and I. Gigli. 1985. Leprosy: altered complement receptors in disseminated disease. J. Invest. Dermatol. $85: 58 \mathrm{~s}-61 \mathrm{~s}$.

18. Minota, S., C. Terai, Y. Nojima, G. D. Ross, M. J. Walport, C. J. Parker, A. F. Leutine, C. R. Fuller, W. J. Young, B. L. Myones,
J. B. Winfield, and P. J. Lachmann. 1984. Low C3b receptor reactivity on erythrocytes from patients with systemic lupus erythematosus detected by immune adherence hemagglutination and radioimmunoassays with monoclonal antibody. Arthritis Rheum. 27:1329-1335.

19. Wilson, J. G., R. M. Jack, W. W. Wong, P. H. Schur, and D. T. Fearon. 1985. Autoantibody to the $\mathrm{C} 3 \mathrm{~b} / \mathrm{C} 4 \mathrm{~b}$ receptor and absence of this receptor from erythrocytes of a patient with systemic lupus erythematosus. J. Clin. Invest. 76:182-190.

20. Gallo, R. C., D. S. Sarin, E. D. Gelmann, M. Robert-Guroff, E. Richardson, V. S. Ralyanaraman, D. Mann, G. D. Sidhu, R. E. Stahl, S. Zolla-Pazner, J. Leibowitch, and M. Popovic. 1983. Isolation of human T-cell leukemia virus in acquired immune deficiency syndrome (AIDS). Science (Wash. DC). 220:865-867.

21. Barre-Sinoussi, F., J. C. Chermann, F. Rey, S. Chamaret, J. Gruest, C. Dauguet, C. Axler-Blin, F. Venizzt-Brun, C. Rouzious, W. Rozenbaum, and L. Montagnier. 1983. Isolation of a T-lymphotrophic retrovirus from a patient at risk for acquired immune deficiency syndrome (AIDS). Science (Wash. DC). 220:868-871.

22. Walsh, D., M. Nardi, and S. Karpatkin, 1984. On the mechanism of thrombocytopenic purpura in sexually active homosexual men. $N$. Engl. J. Med. 311:635-639.

23. Pardo, V., M. Aldana, R. M. Colton, M. A. Fischl, D. Jaffe, L. Moskowitz, G. T. Hensley, and J. Burgoignie. 1984. Glomerular lesions in the acquired immunodeficiency syndrome. Ann. Intern. Med. 101: 429-434.

24. Abrams, D. I., B. J. Lewis, J. H. Beckstead, C. A. Casavant, and W. L. Drew. 1984. Persistent diffuse lymphadenopathy in homosexual men: endpoint or prodrome? Ann. Int. Med. 100:801-808.

25. Ammann, A. J., D. Abrams, M. Conant, D. Chudwin, M. Cowan, P. Volberding, B. Lewis, and C. Casavant. 1983. Acquired immune dysfunction in homosexual men: immunologic profiles. Clin. Immunol. Immunopathol. 27:315-325.

26. Siegal, F. P., C. Lopez, G. S. Hammer, A. E. Brown, S. J. Kornfeld, J. Gold, J. Hassett, S. Z. Hirschman, C. Cunningham-Rundles, B. R. Adelsberg, D. M. Parham, M. Siegal, S. Cunningham-Rundles, and D. Armstrong. 1981. Severe acquired immunodeficiency in male homosexuals, manifested by chronic perianal ulcerative herpes simplex lesions. N. Engl. J. Med. 305:1439-1444.

27. Pitchenik, A. E., M. A. Fischl, and T. J. Spira. 1983. Acquired immune deficiency syndrome in low-risk patients: evidence for possible transmission by an asymptomatic carrier. JAMA (J. Am. Med. Assoc.). 250:1310-1312.

28. Rubinstein, A., M. Sicklick, A. Gupta, L. Bernstein, N. Klein, E. Rubinstein, I. Spigland, L. Fruchter, N. Litman, H. Lee, and M. Hollander. 1983. Acquired immunodeficiency with reversed $T_{4} / T_{8}$ ratios in infants born to promiscuous and drug-addicted mothers. JAMA (J. Am. Med. Assoc.). 249:2350-2356.

29. Scott, G. B, B. E. Buck, J. G. Leterman, F. L. Bloom, and W. P. Parks. 1984. Acquired immunodeficiency syndrome in infants. N. Engl. J. Med. 310:76-81.

30. Masur, H., M. Michelis, J. B. Greene, I. Onorato, R. A. Vande Stouwe, R. S. Holzman, G. Wormser, L. Brettman, M. Lange, H. W. Murray, and S. Cunningham-Rundles. 1981. An outbreak of communityacquired Pneumocystis carinii pneumonia: initial manifestation of cellular immune dysfunction. N. Engl. J. Med. 305:1431-1438.

31. Stahl, R. E., A. Friedman-Kien, R. Dubin, M. Marmor, and S. Zolla-Pazner. 1982. Immunologic abnormalities in homosexual men: relationship to Kaposi's sarcoma. Am. J. Med. 73:171-178.

32. Friedman-Kien, A. E., L. J. Laubenstein, P. Rubinstein, E. Buimovici-Klein, M. Marmor, R. Stahl, I. Spigland, K. S. Kim, and S. ZollaPazner. 1982. Disseminated Kaposi's sarcoma in homosexual men. Ann. Intern. Med. 96:693-700.

33. Scatchard, G. 1949. The attraction of protein for small molecules and ions. Ann. NY Acad. Sci. 51:660-672.

34. Eggerton, G., P. Lind, and J. Sjöquist. 1981. Molecular characterization of the complement activating protein in the venom of the Indian cobra (Naja siamensis). Mol. Immunol. 18:125-133. 
35. Fishelson, Z., and H. J. Muller-Eberhard. 1982. C3 convertase of human complement: enhanced formation and stability of the enzyme generated with nickel instead of magnesium. J. Immunol. 129:26032607.

36. Nydegger, V. E., P. H. Lambert, H. Gerber, and P. H. Miescher. 1974. Circulating immune complexes in the serum in systemic lupus erythematosus and in carriers of hepatitis B antigen. Quantitation of binding to radiolabeled Clq. J. Clin. Invest. 54:297-309.

37. Theofilopoulous, A. N., C. B. Wilson, and F. J. Dixon. 1976. The Raji cell radioimmune assay for detecting immune complexes in human sera. J. Clin. Invest. 57:169-182.

38. Tamerius, J. D., M. K. Pangburn, and H. J. Muller-Eberhard. 1985. Detection of a neoantigen on human C3bi and C3d by monoclonal antibody. J. Immunol. 135:2015-2019.

39. Nelson, R. A. 1953. The immune-adherence phenomenon. Science (Wash. DC). 118:733-737.

40. Dykman, T. R., J. L. Cole, K. lida, and J. P. Atkinson. 1983. Polymorphism of human erythrocyte $\mathrm{C} 3 \mathrm{~b} / \mathrm{C} 4 \mathrm{~b}$ receptor. Proc. Natl. Acad. Sci. USA. 80:1698-1702.

41. Schreiber, R. D. 1984. The chemistry and biology of complement receptors. Springer Semin. Immunopathol. 7:221-249.

42. Walport, M. J., G. D. Ross, C. Mackworth-Young, J. V. Watson,
N. Hogg, and P. J. Lachmann. 1985. Family studies of erythrocyte complement receptor type 1 levels: reduced levels in patients with SLE are acquired, not inherited. Clin. Exp. Immunol. 59:547-554.

43. Gupta, S., and K. Licorish. 1984. Circulating immune complexes in AIDS. N. Engl. J. Med. 310:1530-1531.

44. Lane, H. C., H. Masur, L. C. Edgar, G. Whalen, A. H. Rook, and A. S. Fauci. 1983. Abnormalities of B cell activation and immunoregulation in patients with the acquired immunodeficiency syndrome. N. Engl. J. Med. 309:453-458.

45. Pahwa, S. G., M. Quilop, M. Lange, R. N. Pahwa, and M. H. Greico. 1984. Defective B-lymphocyte function in homosexual men in relation to the acquired immunodeficiency syndrome. Ann. Int. Med. 101:757-763.

46. Melchers, F., A. Erdei, T. Schulz, and M. Dierich. 1985. Growth control of activated, synchronized murine B cells by the C3d fragment of human complement. Complement. 152. (Abstr.)

47. Cowan, M. J., R. O. Brady, and K. J. Widder. 1986. Elevated erythrocyte adenosine deaminase activity in patients with acquired immunodeficiency syndrome. Proc. Natl. Acad. Sci. USA. 83:1089-1091.

48. Moore, J. G., M. F. Frank, H. J. Muller-Eberhard, and N. S. Young. 1985. Decay-accelerating factor is present on paroxysmal nocturnal hemoglobinuria erythroid progenitors and lost during erythropoiesis in vitro. J. Exp. Med. 162:1182-1192. 